\title{
Research on Effective Path of Educational Management of Colleges and Universities under the High Moral Values Establishment and Person Cultivation
}

\author{
Ying Zhou \\ Teaching Affairs Department of Bohai University, Jinzhou Liaoning, 121000
}

Keywords: "set high moral values and cultivate person"; colleges and universities; educational management; path

\begin{abstract}
Set high moral values and cultivate person" is the important connotation of education, however, the differences in moral education level of teachers in colleges and universities, the negative impact of economic development and social transformation and the lack of working mechanism of colleges and universities cause that the implementation is not in place. Based on various difficulties in the implementation, this paper explores implementation strategies from the improvement of evaluation system of colleges and universities and the moral accomplishment of teachers to make better effects.
\end{abstract}

The Third Plenary Session of the 18th Central Committee of the CPC clearly stated that "set high moral values and cultivate person" is the core of developing socialist education with Chinese characteristics, and is the essential requirement for the cultivation of socialist builders and successors with moral, intellectual, physical and aesthetic development, which is a comprehensive deepening of the moral education concept of "taking set high moral values and cultivate person as the fundamental task of education". The concept of "set high moral values and cultivate person" in colleges and universities not only conforms to current economic rapid development, the value appeal of social value diversification, but also the urgent need to shape students' healthy personality and develop socialist education with Chinese characteristics.

\section{The Interpretation of "Set High Moral Values and Cultivate Person"}

In education practice of current colleges and universities, "set high moral values and cultivate person" is the important conceptual guidance of moral education for students with deep connotation. First of all, it manifests the principal objective of education and teaching and takes moral education as an important content. Noble character is an important guarantee for one to be a person and to do things. Secondly, it determines main connotation of education and teaching, which is to cultivate high-quality talents, to guide students to correct direction with noble moral character and cultivate all-round talents. Finally, it proposes to integrate socialist core values into teaching and enrich connotation of education and teaching. Teachers, not only teach knowledge, also undertake the important task of inheriting socialist core values to promote students to foster correct outlooks on life and values and improve their awareness of social responsibility.

\section{The Importance of Educational Management of Colleges and Universities under "High Moral Values Establishment and Person Cultivation”}

\subsection{The reasonability for higher education practice}

Ability and morality are inseparable, and being successful and grown-up also complement each other. Contemporary college students shall be equipped with proficient professional skills and good moral character. Therefore, colleges and universities should put emphasis on moral education, which is the kernel of comprehensive education, and set high moral values and cultivate person is the reasonable proposal put forward by the central party committee based on educational development in China, the strategic theme of current educational reform, and the requirements of 
times to implement educational guidelines, which meets the value demand of higher education to provide basis for higher education practice.

\subsection{The significance on the cultivation of students' healthy character}

Healthy character is the prerequisite for college students to enter the society. The goal of leaning theoretical knowledge is to effectively apply knowledge, and the healthy character can ensure that knowledge learnt are applied into right place. With the cultivation of healthy character, students can more effectively apply knowledge and improve their overall competence to meet the requirements of social development and embody the values. Colleges and universities is the key place for the cultivation of healthy character. It is necessary to pay attention to moral education in the important moment of cultivating character, and it is important to promote to "set high moral values and cultivate person”, which has an important significance on the fostering of correct moral values.

\subsection{The correction of students' current low moral quality}

At present, China's society is developing, however, brings negative impact in addition to the economic development. In recent years, many incidents about the low moral quality of students are reported, for example, some students ignored the elderly lying on the road, did not help the elderly who could barely walk when crossing the road, or having conflict with the elderly because of the seat, which caused discussion in the whole society. Some extreme students made bad behaviors with worse nature, such as the murder by Yao Jiaxin, which has brought a very bad influence on the construction of a good moral culture in colleges and universities, and the public has begun to worry about the cultivation of moral quality in colleges and universities, however, "set high moral values and cultivate person" is the understanding and sublimation of the current morality of students.

\section{Problems in “High Moral Values Establishment and Person Cultivation” in Colleges and Universities}

\subsection{The impact of partial evaluation system}

In recent years, "set high moral values and cultivate person" is repeated and strengthened, however, the results of the implementation in all fields is very little. Constrained by evaluation system, the objective of "setting high moral values and cultivating person" easily deviates. Evaluation of colleges and universities is the important form for higher education to be supervised by the society, and has a positive significance on widening student source, providing information and guidance for consumers of higher education, increasing the understanding of the public, improving the popularity, reputation, and long-term development of colleges and universities. It is undeniable that college and university evaluation has become the main source of school-running ideas for some managers and influences the higher education. Higher education practice is conducted orderly based on most important evaluation index, including scientific research, talent cultivation and school reputation, and the talent cultivation involves discipline construction, the strength of teachers, the quality of graduates, and distinguished alumni, whereas, few in moral education. Therefore, the partial evaluation system cause that the moral education is ignored, which impedes the realization of "setting high moral values and cultivating person".

\subsection{The lack of teachers' ethics}

Teachers of colleges and universities is the main educator and have an important guiding role in the cultivation of moral quality of students. However, most teachers consider theoretical knowledge and technological skills as the most important content in education, and high-level technological skills as the main factor to realize teaching objective, but ignore the morality of teachers and education practice. At the same time, influenced by teacher evaluation mechanism, teachers put most time and energy on scientific research, whereas, the cultivation of moral quality and realization of course progress mainly depend on teachers' sense of responsibility, which has an impact on the realization of "setting high moral values and cultivating person". 


\section{Paths to Implement Educational Management of "High Moral Values Establishment and Person Cultivation”}

Due to partial evaluation system, weak morality of teachers, negative impact of market economy, and many deficiencies in moral education media and mechanism of colleges and universities, at present, there is little results in the implementation of "high moral values establishment and person cultivation". Therefore, it is urgent to actively explore and innovate the implementing paths of "setting high moral values and cultivating person" based on the actual ideological and political education in colleges and universities.

\subsection{To improve college and university evaluation system}

A reasonable evaluation system can complete various work and main content of education practice, and the education and teaching can reach long-term development. Based on main connotation and objective of education and teaching, evaluation mechanism shall implement the people-oriented and comprehensive development ideas for students, make clear that the cultivation of all-round talents is the important content of evaluation system, and promote colleges and universities to uphold the "setting high moral values and cultivating person" and pay attention to moral education for the comprehensive education of students when improving students' knowledge.

\subsection{To pay attention to the construction of teachers' ethics}

In addition to teaching deep knowledge, teachers shall have higher moral quality, which has important guiding role in students. If teachers have higher moral quality, students would be influenced by them to foster benign moral quality, which requires teachers to pay more attention to the cultivation of their own moral quality. Besides, colleges and universities shall build the platform for the construction of teachers' moral quality, praise teachers with higher moral quality to promote teachers to keep their moral concepts firmly and aggregate their own moral strength continuously; teachers are required to learn ethic discipline and moral education psychology and fully take in excellent knowledge to enrich their own moral quality; and cultivation planning of teachers' moral quality shall be included in teacher evaluation system to build new reasonable evaluation mechanism of teachers.

\section{3 build an effective mechanism}

First of all, it is necessary to improve the implementation system of "setting high moral values and cultivating person" in colleges and universities, and build a leadership system for it led by the party branch secretary. It is essential to improve relevant rules and regulations, clarify the scope of responsibility of moral education institutions, change the current status of moral education work, constantly innovate management ideas and implement mechanisms, firmly grasp the initiative of moral education, further analyze the content of students' thinking, prejudge the ideas and behaviors they will generate, actively help students to establish a healthy way of thinking, dispel the wrong ideas, and realize the effectiveness of moral education. Secondly, it is necessary to build a system with cooperation from school, family, and society, and exert the power of unity to jointly solve problems in family education and social education, and clarify the important role of parents in family education, and fully reflect the guiding role of the social environment in social education to effectively change the current difficult state of school education, and strive to build an educational mechanism that integrates school, family, and society to achieve complementary advantages and give full play the important role of the educational philosophy of "high moral values establishment and person cultivation".

"Set high moral values and cultivate person" is the fundamental task of education, and educational management of colleges and universities is a giant system project, which cannot be accomplished in short period of time or relying on a certain person or several person, whereas, which requires wisdom and strength of many people and joint efforts. Therefore, in educational management under "high moral values establishment and person cultivation", it is necessary to 
build reasonable college and university evaluation mechanism to make sure that all work in progress stably; and pay attention to the construction of teachers' ethics in colleges and universities; at the same time, colleges and universities shall improve the implementing system of "high moral values establishment and person cultivation", perfect relevant rules and regulations, more importantly, build the system with cooperation from school, family and society to exert the power of unity to jointly solve problems in family and social education.

\section{References}

[1] Chen Danxiong. On the Plight and Solutions of "High Moral Values Establishment and Person Cultivation” in Colleges and Universities [J]. Higher Agricultural Education, 2014(03).

[2] Feng Xiaoling. On Practice Path and Working Mechanism of "High Moral Values Establishment and Person Cultivation” [J]. Radio\& TV Journal, 2013(08).

[3] Zhang Ximei. The Scientific Mode Construction of Management Mechanism of Ideological and Political Education in Colleges and Universities [J]. Education and Vocation, 2010(01).

[4] Fang Xiaozhen. Theoretical Guidance and Practice Path of "High Moral Values Establishment and Person Cultivation" in Colleges and Universities [J]. Ideological and Political Education Research, 2013(10).

[5] Hu Jintao. Firmly Advance along Socialist road with Chinese Characteristics, Struggle for the Building of a Moderately Prosperous Society in an All-round Way -The Report in the $18^{\text {th }}$ National Congress of the CPC [M]. Beijing: People's Publishing House, 2012. 